\title{
Transnational Imagination of China in Ezra Pound's and William Carlos Williams' Poetics
}

\author{
Tang Wei ${ }^{1,2}$ \\ ${ }^{1}$ School of Foreign Languages, Nanjing University, Nanjing, China \\ ${ }^{2}$ School of Foreign Languages, Nanchang University, Nanchang, China
}

Email address:

tangwei@ncu.edu.cn

\section{To cite this article:}

Tang Wei. Transnational Imagination of China in Ezra Pound's and William Carlos Williams' Poetics. English Language, Literature \& Culture. Vol. 6, No. 1, 2021, pp. 7-13. doi: 10.11648/j.ellc.20210601.12

Received: February 9, 2021; Accepted: March 2, 2021; Published: March 10, 2021

\begin{abstract}
As a modernist movement in poetry emphasizing the clarity of expression through the use of precise visual images, Imagism drew inspiration from the poetic forms of different countries, among which an influential one was Chinese poetry. As the pioneer of the movement, Ezra Pound is noted for his profound interest in Chinese ideograph and skillful appropriation of Chinese poetry in his own works which inspire and influence a host of American poets of the Modern period including William Carlos Williams. Though Pound and Williams were both labelled as imagist poets, they departed from each other in their later poetics. Researchers have long noticed this departure, but paid scant attention to the influence of Chinese poetry on it. This paper is intended to conduct a study on the influence of Pound's and Williams' transnational imagination of China on their poetics which leads to two opposing directions in dealing with Chinese poetry and culture in modern American poetry. It tries to point out that, while Pound's appropriation of classical Chinese poetry and traditional Confucian culture is in the purpose of renovating post-Victorian poetic style and attaining a cosmopolitan poetics, Williams' appropriation of Chinese poetry focuses more on refining stylistic techniques and enhancing an objectivist poetics to better accommodate the local American imageries and colloquial American English.
\end{abstract}

Keywords: Ezra Pound, William Carlos Williams, Poetics, Classical Chinese Poetry, Chinese Culture

\section{Introduction}

In Ezra Pound Among the Poet, Thomas Parkinson asserts the relations between Pound and Williams have a rich complexity that gives them symbolic importance in the history of American poetry. He also exclaims that Pound and Williams were "among our great liberators, and they are among the great contrasts in the American legacy, equivalent to Whitman and James in their achievements and in the charge that their testaments leave to their godchildren" [1]. Though Williams was greatly inspired by Pound to compose imagist poetry in the early stage of his career, he later departed from Pound's imagism to develop "objectivism" as a new poetics. Williams saw his poetic project as a distinctly American one. He sought to renew language through the fresh, raw idiom that grew out of America's cultural and social heterogeneity, at the same time freeing it from what he saw as the worn-out language of British and European culture which Williams thought both Elliot and Pound purported to transcend but never succeeded in fulfilling it.

Many critics have noticed this departure between Pound and Williams. For example, Chinese critic Wu Xinyu applied Harold Bloom's theory of "anxiety of influence" to argue that Williams" objectivism "corrects" and "rebels" Pound's imagism to counter the powerful, oppressive and miserable patriarchal force from Pound [2]. Fu Hao, in another article, argues that Pound's and Elliot's poetry couldn't get rid of the influence of traditional European poetry and are conservative and backward-looking, while Williams' poetry focuses on American locality and seeks a new poetic style for colloquial American English, which is innovative and forward-looking [3].

While both Pound and Williams evinced profound interest in classical Chinese poetry and traditional Chinese culture, they also displayed a lot of difference in ways of understanding and borrowing from China. Chinese scholar Qian Zhaoming pointed out that "there is a difference between his and Pound's sense of China, and there is a difference between their ways of borrowing" [4]. However, Professor 
Qian's book focuses more on the similarity and significance between Pound's and Williams' interaction with China. In light of this, this paper is intended to conduct a research on the connection of their different imagination of China to their distinctive poetics. It tries to point out that while Pound's appropriation of classical Chinese poetry and traditional Confucian culture is in the purpose of renovating post-Victorian poetic style and attaining a cosmopolitan poetics, Williams' appropriation of China focuses more on refining stylistic techniques and enhancing an objectivist poetics to better accommodate the local American imageries and colloquial American English.

\section{Pound's Imagination of China and His Cosmopolitan Poetics}

In 1915, Pound once wrote on Poetry, a famous magazine of poetry founded by the poet and his friend Harriet Monroe, "Liu Ch'e, Chu Yuan, Chia I, and the great vers libre writers before the Petrarchan age of Li Po, are a treasury to which the next century may look for as great a stimulus as the renaissance had from the Greeks" [5]. In another word, Pound evinced great interest in classical Chinese poetry and saw Chinese poetry as a refreshing fountain of inspiration for modern English poetry.

While Pound received no formal instruction in the Chinese language, his interest in Chinese poetry would have never been the same if he hadn't gained possession of the sinologist Ernest Fenollosa's manuscripts on Chinese and Japanese literature in 1913. Based on Fenollosa's notes on translation and understanding of classical Chinese poetry, Pound selected to retranslate some of the Chinese poems and published under the title of Cathay in 1915. However, Pound's interest in the translation of Chinese poetry was not incidentally evinced but closely related to his experiment with Imagism as a rebel against and a renovation of the banal post-Victorian poetic style. In the year around 1908, some English and American poets began to start a movement in the purpose of reforming and correcting the banal, artificial manner of the romantic-style poetry during the early twentieth century by its emphasis on concrete imagery and concise language and its advocacy of free verse. The movement was later labeled as Imagist Movement which marked the commencement of American modernist poetry. As a pioneer of imagist movement, Ezra Pound insisted that poetry require a precise and economic use of language and that the poet should always use the "exact" word, stripping the writing down to the "barest essence". Hence, he found inspiration in classical Chinese poetry, a type of poetry which typically applies a large combination of assorted imageries in brief lines. He admired the terse style and lively images of Chinese classical poetry and he hoped to use the same style and the same image expression to reform traditional English poetry. Critics remarked, "It was Cathay that first introduced the twentieth-century reading public to Chinese poetry. In it, Pound created a proper vehicle for getting Chinese poets across to his contemporaries, disregarding their 'rhymes' and 'tones' while following their verbal constructions and methods of presentation" [6].

As Pound later departed with Amy Lowell on Imagism and pioneered, with other artists, another distinctive school of modern poetry - Vorticism, his Cathay could also be seen as coinciding with his move toward Vorticism. In Cathay, his choice and collection from nearly 150 poems based on Fenollosa's manuscripts were accordingly made under the influence of his Vorticist notion of the Image. He found a model that at once mirrored and challenged his developing poetics in Li Po and other Chinese poets. In his 1918 essay on "Chinese Poetry", he made it clear that he translated Chinese poetry precisely "because Chinese poetry has certain qualities of vivid presentation; and because certain Chinese poets have been content to set forth their matter without moralizing and without comment" [6].

Chinese scholar Tao Naikan asserts in his book Pound and Chinese Culture, "If we are to see Pound's poetry as an integral entity and use one word to generalize the most conspicuous feature of it, I suggest we could probably use the word of 'cosmopolitanism" " [7]. Tao regards that Pound's "cosmopolitan" poetics highly exemplifies the spirit of Goethe's "world literature" in his interdisciplinary incorporation of different writing styles and languages from different cultures. It is apparent that before Pound resorted to the appropriation of Chinese poetry in his own poetry writing he had aspired to attain a cosmopolitan poetics via borrowing from different literary styles in different countries. For instance, 'In his essay 'Vorticism', Pound acknowledged for the first time in his career his indebtedness to Japanese poetics in general and the art of haiku in particular" [8]. It was also in this essay that his famous haiku-like poem "In a Station of the Metro" appeared. According to Nadel, "Imagism evolved as a reaction against abstraction in favor of precision, replacing Victorian generalities with the clarity found in Japanese haiku and ancient Greek lyrics" [9]. Together with Pound's intended appropriation of Japanese and Greek literary resources, the encounter with and appropriation of Chinese poetry marked a significant step in Pound's development of a cosmopolitan poetics. As Michael Alexander remarks, "He supplied the first truly poetic translations of classical Chinese poetry. His selective revival of Catullus and Propertius showed how the less public poets of our first metropolitan, imperial and corrupt Western civilization had resisted 'current exacerbations'. These translations and adaptations were the fruit of a deliberate survey of civilized poetry, an exploration growing out the methods and materials of Comparative Literature. Pound was not subject to that provincialism in time which Eliot diagnosed as a modern illness; on the contrary, he

\footnotetext{
1 Tao explains that he means to use the term "cosmopolitanism" to refer to the Goethe's concept of "Weltliteratur", namely, "world literature". Goethe used the concept of "Weltliteratur" in several of his essays in the early decades of the nineteenth century to describe the international circulation and reception of literary works in Europe, including works of non-Western origin. Karl Marx and Friedrich Engels used the term in their Communist Manifesto (1848) to describe the "cosmopolitan character" of bourgeois literary production.
} 
preferred Homer and the Chinese Book of Odes" [10].

Along with his translation and appropriation of classical Chinese poetry comes Pound's profound interest in Chinese culture, especially the traditional Chinese Confucian culture, in his seminal work - The Cantos. Actually, Pound was conceiving the creation of his most important work - The Cantos, when he was translating and imitating the great Chinese masters of poetry. The first few cantos were drafted in the year of 1915 when Cathay was published. Many scholars of Pound regard Cathay as the solid foundation and the starting point of The Cantos. His adoption of the "ideogrammic method" for The Cantos is directly linked to his preoccupation with Fenollosa's essay "The Chinese Written Character as a Medium for Poetry". All through The Cantos, there appear many characters that represent the core values of traditional Chinese Confucian culture. It is obvious that Pound is intended to summon fresh inspiration from the incorporation of the ideogrammic Chinese characters and traditional Confucian culture with other literary styles and cultures, in the purpose of creating a kind of poetics which could resist the barren land of Western thought and the banality of Victorian poetic style. As Hayot remarks on Pound's interest in Chinese character and culture, "Confucian thought and ideographic writing could be separated from China so that he could call for the modification of the contemporary West by the East" [11]. By doing this, Pound also accomplishes the purpose of creating a cosmopolitan poetics. For instance, the first Chinese character that appears in The Cantos is xin 信 whose meanings involve "trust", a core value of Confucian culture, and "confidence", appears next to the Greek quotation "Constans proposito.../ Justum et Tenacem" which is from Horace and means "Constant in purpose.../Just and enduring" [12]. Pound's understanding of the character is on the typical ideogrammic structure of Chinese characters. Xin 信 is made up of two parts: ren 人, which means a person, on the left side and yan 言, meaning word, on the right side. Therefore, Xin 信, by combining the two parts together, means a person who can stand by his word, namely, a person who can always be trusted. Apparently, by putting this character next to the Greek quotation which reflects and repeats the similar idea and conception, Pound aspires to emphasize "the common ideal of 'trust' (or constancy in meaning) across world and time" [11]. Here in this typical example (quoting Chinese characters based on the understanding of their different ideographic structures is prevalent in The Cantos, especially in The Pisan Cantos), it is obvious that Pound, by incorporating the Chinese and Greek characters and culture together, attains the purpose of transcending the barrier of national boundaries and expressing some cosmopolitan interests and values among human beings.

\section{Williams' Imagination of China and His Objectivist Poetics}

While Pound sticks to his pursuit of a cosmopolitan poetics to renew the barrenness and banality of the post-Victorian
English poetry, Williams emphasizes more on a poetics based on the American locality. Williams always denies that he has been influenced by a certain poet or poetry from a certain country. However, when we conduct a careful research on Williams and his poetry writing, we could find that he himself and his poetry writing are closely related to Pound and Chinese poetry and culture. Eliot Weinberger once mentioned, "Cathay had led Williams to Giles' History ${ }^{2}$, and reference to China and Chinese poetry appear as early as Kora in Hell (1918)" [13]. He went on to argue that, "Williams, however, apparently kept the conversation to Chinese poetry, and their four-year collaboration ${ }^{3}$ resulted in 'The Cassia Tree,' a group of 37 poems, published in 1966, after Williams' death" [13]. Although Pound and Williams were both influenced by Chinese poetry and culture in their poetry writing and poetics, the degree and the way they were influenced was remarkably different. Pound evinced a consistently profound interest in Chinese poetry and culture ever since he gained possession of Fenollosa's manuscripts and earnestly put in into practice whether in his translation of Chinese poetry or in his poetry writing. However, Williams' appropriation of Chinese poetry and culture is inconsistent and can be divided into two different stages. The first stage coincides with the early stage of Williams' career as a poet from 1916 to 1920 when his idiosyncratic "minimal spatial poetry" came into being under the influence of the ancient Chinese poets like Li Po, Po Chu-I and so on. The second stage happens in the late stage of his poet career from 1957 to 1961 when he cooperated with the Chinese American David Rafael Wang in translating classical Chinese poetry and returned back to his "minimal spatial poetry" writing from his experiment with "triadic stanza" - a new kind of poetic style that Williams experimented in his Paterson.

Different from Pound who has won high prestige among the modern poets in his twenties, Williams was late in his poetic achievement when he, after thirty-five, created an idiosyncratic poetic style which features extremely short verse lines and concise imageries. Qian Zhaoming argues in his article, "While the techniques used by Williams to cut the verse lines were learned from the Cubist painters, the way he reorganized them into a minimal four-line stanza was seemingly learned from classical Chinese poetry" [14]. According to Qian who has been to library of Fairleigh Dickinson University, New Jersey where Williams' collection of books is stored, among the books that Williams has purchased from 1916 to 1920 were two books introducing about Chinese literature and poetry - H. A. Giles' A History of Chinese Literature (1901) and Arthur Waley's One Hundred and Seventy Chinese Poems (1919) [14]. While Giles' book does arouse Williams' interest in the spatial structure and the artistic characteristics of classical Chinese poetry, especially the poetry of Po Chu-I, and Williams has also hinted in his

2 History here refers to H. A. Giles' A History of Chinese Literature which was published in 1901 .

3 It refers to the cooperation between Williams and David Rafael Wang (1931-1977) in translating Chinese poetry from the year of 1957 when Williams was 74 . 
poem "To the Shade of Po Chu-I" (1920) that he was greatly inspired by the great ancient Chinese poet, we could throw more light on the connection between Williams' early poetry and classical Chinese poetry by comparing the similarities between them:

Precise image in minimal structure

One of the usual sources of Williams' early poetry is ordinary, everyday objects. As he pointed out in the Foreword of his Autobiography, he wanted people to realize that "even the most trivial happenings may carry a certain weight" [15]. By doing this, Williams is obviously influenced by Imagism which was popular during that time. There are a number of Williams' poems, especially those extremely short ones, which highly represent the cardinal principles of Imagism "direct treatment of the 'thing', whether subjective or objective" and "to use absolutely no word that does not contribute to the presentation". Therefore, Williams was enthusiastically interested in the concise form and precise images of classical Chinese poetry, especially the typical Tang Dynasty poetry which puts a great emphasis on their selection and juxtaposition of images to depict an ordinary object or to narrate an incident. The most typical and famous one is his most anthologized "The Red Wheelbarrow".

$$
\begin{gathered}
\text { so much depends } \\
\text { upon } \\
\text { a red wheel } \\
\text { barrow } \\
\text { glazed with rain } \\
\text { water } \\
\text { beside the white } \\
\text { chickens. }
\end{gathered}
$$

This famous poem depicts three simple images: wheelbarrow, rain water and white chickens in four extremely short sentences. Williams forcefully breaks each sentence into two verse lines, three words in the first line and one single word in the second, in the purpose of using "small structures to force attention to infinitesimal units of meaning within the poem (sounds, stress patters, line breaks)" [16]. It is often regarded as written in a brief, haiku-like free-verse form, but it also apparently resembles the typical Jue $j u^{5}$ style in Chinese classical poetry. As a matter of fact, it is said to be "an intended imitation of the famous poet Bai Juyi (Po Chu-I)'s Jue ju - a five-line epigram" [14]. Williams probably learned this style from Giles' A History of Chinese Literature in which Giles explains and thinks highly of the stylistic structure of $J u e j u$ as "although consisting of only twenty or twenty-eight words, according to the measure employed, it is just long enough for the poet to introduce, to develop, to embellish, and to conclude his theme in accordance with certain established

4 All poems by Williams in this paper are cited from The Collected Poems of William Carlos Williams: 1909-1939. New York: New Directions Publishing, 1991.

5 Jue ju is a style of jintishi (modern form poetry) that grew popular among Chinese poets in the Tang Dynasty (618-907), although traceable to earlier origins. Jueju poems are always quatrains; or, more specifically, a matched pair of couplets, with each line consisting of five or seven syllables. http://en.wikipedia.org/wiki/Jueju laws of composition" [17]. Qian argues in his article that if we are to reorganize the dissembled verse lined back into its original form, namely four sentences, we could see its extremely similar structure as jue ju [14].

Visual effect in plain language

In The Chinese Written Character as a Medium for Poetry, an unprecedented work on Chinese language and poetry, Fenollosa asserts, "One superiority of verbal poetry as an art rests in its getting back to the fundamental reality of time. Chinese poetry has the unique advantage of combining both elements. It speaks at once with the vividness of painting, and with a mobility of sounds" [18]. The formalistic and visual effects of Chinese poetry as pointed out by Fennollosa influence Pound and Williams to a considerable degree. Like Pound, Williams also tried to perfect a style whose visual effect in plain language was modeled on that of the Chinese ideogram. For instance, his "Poem" is typical of this genre: as the cat

climbed over the top of the jam closet first the right forefoot carefully then the hind stepped down into the pit of the empty flowerpot

Willard Bohn remarks, "What this poem lacks in expansiveness it more than makes up for in the precise sweep of its lines. The secret of its expressiveness, like the ideogram's, lies in the concision with which the images are evoked. Like a Chinese calligrapher, Williams deftly sketches the most important details with a few quick strokes of the pen" [19]. Therefore, it is self-evident that Williams' intended appropriation of Chinese poetry also serves the purpose of attaining a certain kind of profound visual effect via plain language that is typical of classical Chinese poetry. One of the most striking visual features in Williams' poetry is that he extensively makes use of the expressions of color and daily objects like he is painting, which is also typical of classical Chinese poetry whose visual effects are achieved, first and foremost, by the application of color images, ordinary objects and then the spatial construction of the images as a unified picture. Take the famous poem The Willow by He Zhizhang, a great poet of Tang Dynasty, as an example:

The slender beauty's dressed in emerald all about;

A thousand branches droop like fringes made of jade.

But do you know by whom these slim leaves are cut out?

The wind of early spring is sharp as scissor blade. ${ }^{6}$

In the first two lines, there are two color images - "emerald" and "jade" which lay the foundation for a painting. Then it is the metaphor of willow as a beautiful girl, represented by the

6 The English version of the poem is cited from the famous Chinese translator $\mathrm{Xu}$, Yuanchong in his Tang Poetry (I) published by Dolphin Books in 2013. 
noun images "beauty", "fringes" and the verb image "droop" which completes the spatial construction of the soft and beautiful picture of a willow tree in the springtime as a "slender beauty". Late in his life, Williams said in an interview: “As I've grown older, I've attempted to fuse the poetry and painting to make it the same thing...to give a design. A design in the poem and a design in the picture should make them more or less the same thing" [20]. When composing poems, he attempts to adopt the painter's devices and techniques, such as harmony color and contrast of color, to display daily-life scenes so as to arouse wild imagination of the readers and stir aesthetic emotions as well. Williams once wrote to Pound in a letter, "All I do is try to understand something in its natural colors and shapes," which indicated that color and shape are the most fundamental to him [21]. In "The Red Wheelbarrow", Williams displays a serene picture of a graceful daily-life scene which is typical of a traditional Chinese painting. In the third line, the hue of rain is gray, which serves as the background of the still-life. The picture plane looks misty and harmonious against the gray raining sky. According to colorists, gray can serve as mediator in painting, and quite match the bright colors, so it is usually used to make the motif stand out. Accordingly, the use of gray renders the picture plane to be gentle, graceful, peaceful and tranquil, just as the colors in The Willow. Another example is "Between Walls", in which Williams adopts another painterly device contrast of color zone - the contrast between the whole (the wall) and the partial (cinders and broken pieces of bottle) - to make images stand out and impress the readers visually.

$$
\begin{aligned}
& \text { the back wings } \\
& \text { of the } \\
& \text { hospital where } \\
& \text { nothing } \\
& \text { will grow lie } \\
& \text { cinders } \\
& \text { In which shine } \\
& \text { the broken } \\
& \text { pieces of a green } \\
& \text { bottle }
\end{aligned}
$$

Although Williams' early poetry shows a great similarity with Chinese poetry, he gave up the "minimal spatial" style for a "triadic stanza" whose "variant foot" he regarded as better fits the rhythm of American English. However, after he met the Chinese American David Rafael Wang and started to translate Chinese poetry with him in 1957, Williams was enthralled by Chinese poetry again and began to give up his experiment with "triadic stanza" in his long-poem collection Paterson and returned to the "minimal-spatial" style in the writing of his last poetry collection - Poetry from Brueghel (1962). For instance, poems like "Iris" and "Short Poem" from this collection remind us of Williams' attempt to model his poetry writing on the stylistic rules and techniques of classical Chinese poetry. In fact, Williams intentionally appropriated the traditional Chinese poetic styles and techniques to create and perfect an idiosyncratically minimal, spatial style which is epitomized by his famous phrase "no ideas but in things".

However, though there are striking similarities between
Williams' poetry and Chinese poetry, he intended his appropriation of China to achieve the purpose of enhancing an objectivist poetics to better accommodate the local American imageries and colloquial American English, which is remarkably differently from Pound's aspiration of attaining a cosmopolitan poetics.

Williams' objectivist poetics and conception of culture originated as an opposition to the culture inherited from England and Europe by poets like Longfellow and Bryant which he regards as lacking the "locality upon which originality is rested" [22]. By learning from Edgar Allen Poe's way of handling language, Williams "detects the 'local' and the 'original', both of which he defines within a concept of culture tied to its etymological roots - to cultivate, 'to work with a thing until it be rare' rather than to 'build an unrelated copy upon it"” [23].

Williams' preference for American locality and originality is highly epitomized in his poetry writing. Most of his poems, from the early short ones in Spring and All to the later long ones in Paterson, focus on the locality that he is close to and familiar with. Hence, Ronald E. Martin argues, "Locality in Williams' works is virtually a constant presence, from the 'filthy Passaic' in the first of his collected poems, 'The Wanderer,' to the presence of that same river in the sixth book of Paterson, left uncompleted at his death" [24]. His sense of local culture and history is also represented by his In the American Grain - a modern classic reconstructing a live tradition for Americans and influencing a lot of Americans such as the famous writer Maxine Hong Kingston. Considering Williams' appropriation of China in his poetry writing and the similarities between his poetry and Chinese poetry presented above, we can safely draw the conclusion that Williams intended his appropriation of China to achieve the purpose of enhancing a "localized" poetics to better accommodate the local American scenes and language, which is remarkably differently from Pound's aspiration of attaining a "globalized" cosmopolitan poetics.

Williams' appropriation of China is also to a certain degree relevant to his poetics of Objectivism. In March, 1928, Williams was introduced by Pound to Louis Zukofsky, with whom and other artists he started a new poetic movement Objectivism as the supplementation and development of Imagism. Though when talking about Objectivism in his Autobiography (1951), Williams described it as "a rejection of Imagism", the two do share a lot in common. For instance, "like the Imagists, the Objectivists were concerned with precision, with dramatized experience rather than statement, and with rhythms and cadences that were the necessary products of a particular moment and voice [25]. Williams argued, "The poem being an object (like a symphony or cubist painting) it must be the purpose of the poet to make of his words a new form: to invent, that is, an object consonant with his day. This was what we wished to imply by Objectivism, an antidote, in a sense, to the bare image haphazardly presented in loose verse" [22]. However, there are also differences between Objectivism and Imagism. For example, "there is a greater emphasis on the formal structure of the poem in 
Objectivist writing, and a more intense interest in the musical properties of poetry" [25]. The Chinese scholar Fu Hao contends that Williams has already depicted poem as an independent object in his early collection - Spring and All, of which poems like "The Red Wheelbarrow" have had some characteristics of objectivist poetry with their omission of subjects, forcing readers' attention to things as objects, and their visual effects in regularly printed structure [3]. Therefore, Williams' Objectivism can be seen as a further development and extension of Imagism, which is also substantially attributed to classical Chinese poetry.

There are also critics who paid attention to the similarity between Williams' poetics and traditional Chinese Taoist aesthetics. The Chinese American scholar Wai-lim Yip argues that Taoism "urges us to go further into the status of abandoning the individual name and institution by means of questioning the common sense so as to be correspond to Tao and to present the vivid nature as it is. These characteristics were revealed obviously in classical Chinese poetry, and they formed a distinguished aesthetic effect. The pursuit of the 'thing itself' in modern American poetry is exactly using the Taoist aesthetics as its important media" [26]. Yip cites many modern American poets including Pound and Williams as examples experimenting with new styles and techniques in poetry writing to explain the connection between them and Chinese Taoist aesthetics. While he points out that both Pound and Williams learn and imitate the skills of "spatial isolation", "grammatical isolation" and "superstition" (overlapping images) from Chinese classical poems in their poetry writing, he contends that Pound, by applying the "ideogrammic method", breaks the linear movement in traditional Western-style poetics and transcends the rigid and ossified Western grammar and conception of time, incorporates all kinds of cultural elements together and situates his readers in a totally different cultural and historical space-time continuum, achieving a cosmopolitan bird-eye view in his poetics [26]. However, when discussing about Williams and his poetry experiments attributed to Chinese poetry, Yip asserts Williams' appropriation of these skills from classical Chinese poetry enhances the instantaneous visual effect of his poems and readers of his poems are left with isolated images holding not much valid syntactic relation between them. It is totally by the readers' instantaneous experience of the immediacy of each image that they can gather a spatial relation and extension between images, which is typical of the Taoist aesthetic experience readers of a classical Chinese poetry or viewers of a traditional Chinese shan shui painting can gather [26]. As a matter of a fact, what Yip discusses on the connection between Williams' appropriation of Chinese poetry and Taoist aesthetics is closely related to his objectivist poetics with its greater emphasis on the formal structure of the poem and a more intense interest in the visual and musical properties of poetry.

Therefore, considering the intense connection between Williams' poetry creation and classical Chinese poetry, it is reasonable to believe that Williams' advocacy of an objectivist poetics is profoundly influenced by his appropriation of
Chinese poetry which Williams is intended to apply into better accommodating the American locality and language.

\section{Conclusion}

As the leading poets of modern American poetry, both Pound and Williams were greatly influenced by classical Chinese poetry. However, the way and the purpose of their appropriation of Chinese poetry in their poetics varied remarkably. Pound mimicked the ideographic feature of Chinese poetry and incorporated an assortment of alien cultures into his poetry so as to achieve a minimalist poetic form with only images and a cosmopolitan poetics, while Williams, though siding with Pound at an early stage, later applied classical Chinese poetry mainly to attain an objectivist poetics which departed from imagism. Via their transnational imagination of Chinese poetry and culture, Pound and Williams aspired to renovate the Anglo-American poetic style and react against the sentimental subjectivity and grand narratives of the romantic and Victorian poetry. Nevertheless, their poetic style began taking different paths. Pound sought to "make it new" by looking backward - juxtaposing images from traditional culture of different countries, which inevitably led to his elusive poetic style. He meant to "use the Chinese aesthetic traditions to provide a critique of the West" [27], but his cosmopolitan poetics was too ambitious to leave room for native American elements. By contrast, Williams chose to "make it new" by looking forward - assimilating alien poetic form only to help him better accommodate the local American objects and plain language, which substantially influenced the later-generation American modernist and postmodernist poets.

\section{References}

[1] George Bornstein (1985). Ezra Pound Among the Poet, Chicago: University of Chicago Press, 149.

[2] Wu, Xinyu (2009). "From Ezra Pound's Imagism to W. C. Williams' Objectivism", in Foreign Literature Review, Vol. 1, pp. 164-176.

[3] Fu, Hao (2014). "Williams vs. Pound and Elliot: Their Poetics", in Foreign Literature, Vol. 4, pp. 15-23.

[4] Qian, Zhaoming (1995). Orientalism and Modernism: The Legacy of China in Pound and Williams. Durham: Duke University Press, 109.

[5] Ruthven, K. K (1969). A Guide to Ezra Pound's Personae, 1926. California: University of California Press. 222.

[6] Tryphonopoulos, Demetres P. \& Stephen Adams (2005). The Ezra Pound Encyclopedia. Westport: Greenwood Publishing Group, Inc, 53, 54.

[7] Tao, Naikan (2006). Pound and the Chinese Culture. Beijing: Beijing Normal University Press, 3.

[8] Hakutani, Yoshinobu (2009). Haiku and Modernist Poetics. New York: Palgrave Macmillan, 3. 
[9] Nadel, Ira B. (1999). The Cambridge Companion to Ezra Pound. Cambridge: Cambridge University Press, 2.

[10] Alexander, Michael (1981). The Poetic Achievement of Ezra Pound. California: University of California Press, 46.

[11] Hayot, Eric R. J. (2009). Chinese Dreams: Pound, Brecht, Tel Quel. Ann Arbor: University of Michigan Press, 47, 48.

[12] Pound, Ezra (1975). The Cantos. London: Faber\&Faber Limited, 171.

[13] Weinberger, Eliot [2004]. The New Directions Anthology of Classical Chinese Poetry. New York: New Directions Publishing, xxv.

[14] Qian, Zhaoming (2010). "Williams' Minimal Spatial Design and His Preoccupation with Chinese Poetry", in Foreign Literature, Vol. 1, pp. 57-66.

[15] Williams, William Carlos (1967). The Autobiography of William Carlos Williams. New York: New Directions Publishing.

[16] Greene, Roland \& Stephen Cushman (2012). The Princeton Encyclopedia of Poetry and Poetics. Princeton: Princeton University Press, 294.

[17] Giles, Herbert A. (2008). A History of Chinese Literature. Wildside Press LLC, 146.

[18] Weinberge, Eliot (2004). The New Directions Anthology of Classical Chinese Poetry. New York: New Directions Publishing, 193.
[19] Bohn, Willard (2001). Modern Visual Poetry. Cranbury: Associated University Press, 34.

[20] Halter, Peter (1994). The Revolution in the Visual Arts and the Poetry of William Carlos, New York: Cambridge University Press, 171.

[21] Pound, Ezra (1996). Pound/Williams: Selected Letters of Ezra Pound and William Carlos Williams. New York: New Directions Publishing, 92.

[22] Williams, William Carlos (1966). The William Carlos Williams Reader. New York: New Directions Publishing, 366.

[23] Kinnahan, Linda A. (1994). Poetics of the Feminine: Authority and Literary Tradition in William Carlos Williams, Mina Loy, Denise Levertov, and Kathleen Fraser. New York: Cambridge University Press, 119.

[24] Martin, Ronald E. (1991). American Literature and the Destruction of Knowledge: Innovative Writing in the Age of Epistemology. Durham: Duke University Press, 287.

[25] Noel-Tod, Jeremy \& Ian Hamilton (2013). The Oxford Companion to Modern Poetry in English. Oxford: Oxford University Press, 695.

[26] Wai-lim, Yip (2004). "Taoist Aesthetics, Chinese Poetry and Modern American Poetry”, in Chinese Poetry Studies, Vol. 00, pp. 1-46.

[27] Kent, Su (2021). "Landscapes and Taoism in Ezra Pound's Cantos", in Neohelicon. 